\title{
The selfsufficient P450 RhF expressed in a whole cell system selectively catalyses the 5hydroxylation of diclofenac
}

DOI:

10.1002/biot.201600520

\section{Document Version}

Accepted author manuscript

Link to publication record in Manchester Research Explorer

Citation for published version (APA):

Klenk, J. M., Nebel, B., Porter, J., Kulig, J. K., Hussain, S., Richter, S. M., Tavanti, M., Turner, N., Hayes, M. A., Hauer, B., \& Flitsch, S. (2017). The selfsufficient P450 RhF expressed in a whole cell system selectively catalyses the 5hydroxylation of diclofenac. Biotechnology Journal (Print). https://doi.org/10.1002/biot.201600520

\section{Published in:}

Biotechnology Journal (Print)

\section{Citing this paper}

Please note that where the full-text provided on Manchester Research Explorer is the Author Accepted Manuscript or Proof version this may differ from the final Published version. If citing, it is advised that you check and use the publisher's definitive version.

\section{General rights}

Copyright and moral rights for the publications made accessible in the Research Explorer are retained by the authors and/or other copyright owners and it is a condition of accessing publications that users recognise and abide by the legal requirements associated with these rights.

\section{Takedown policy}

If you believe that this document breaches copyright please refer to the University of Manchester's Takedown Procedures [http://man.ac.uk/04Y6Bo] or contact uml.scholarlycommunications@manchester.ac.uk providing relevant details, so we can investigate your claim.

\section{OPEN ACCESS}


Research Article

The self-sufficient P450 RhF expressed in a whole cell system selectively catalyses the 5-hydroxylation of diclofenac

Jan M. Klenk, ${ }^{2}$ Bernd A. Nebel, ${ }^{2}$ Joanne L. Porter, ${ }^{1}$ Justyna K. Kulig, ${ }^{3,4}$ Shaneela A. Hussain, ${ }^{1}$ Sven M. Richter, ${ }^{2}$ Michele Tavanti, ${ }^{1}$ Nicholas J. Turner, ${ }^{1}$ Martin A. Hayes, ${ }^{3}$ Bernhard Hauer, ${ }^{2}$ and Sabine L. Flitsch ${ }^{1}$

${ }^{1}$ School of Chemistry, Manchester Institute of Biotechnology, The University of Manchester, M1 7DN, UK.

${ }^{2}$ Institute of Technical Biochemistry, University of Stuttgart, Allmandring 31, 70569 Stuttgart, Germany.

${ }^{3}$ Cardiovascular and Metabolic Diseases DMPK, Innovative Medicines and Early Development Biotech Unit, AstraZeneca, Pepparedsleden 1, Mölndal, 431 83, Sweden.

${ }^{4}$ Present address: Crop Science Division, Bayer AG, Alfred Nobel Str. 50, 40789 Monheim am Rhein, Germany.

Correspondence: Prof. Sabine L. Flitsch, School of Chemistry, Manchester Institute of Biotechnology, The University of Manchester, M1 7DN, UK.

E-mail: sabine.flitsch@manchester.ac.uk

Prof. Bernhard Hauer, Institute of Technical Biochemistry, University of Stuttgart, Allmandring 31, 70569 Stuttgart, Germany.

E-mail: bernhard.hauer@itb.uni-stuttgart.de

Dr. Martin Hayes, Cardiovascular and Metabolic Diseases DMPK, Innovative Medicines and Early Development Biotech Unit, AstraZeneca, Pepparedsleden 1, Mölndal, 431 83, Sweden. 
E-mail: martin.hayes@astrazeneca.com

Keywords: Biocatalysis, Cytochrome P450, Diclofenac, Drug metabolism, Fermentation, Regioselectivity. 
Abbreviations: ALA, aminolevulinic acid; BM3, cytochrome P450 from Bacillus megaterium; cdw, cell dry weight; cww, cell wet weight; HPLC, high-performance liquid chromatography; IMAC, immobilised metal affinity chromatography; IPTG, isopropyl $\beta$-D1-thiogalactopyranoside; IR, infrared; MS, mass spectrometry; NADPH, nicotinamide adenine dinucleotide phosphate; NMR, nuclear magnetic resonance; NSAID, non-steroidal anti-inflammatory drug; P450, cytochrome P450 monooxygenase; RhF, cytochrome P450 from Rhodococcus sp. strain NCIMB 9784. 


\begin{abstract}
P450 monooxygenases are able to catalyse the highly regio- and stereoselective oxidations of many organic molecules. However, the scale-up of such bio-oxidations remains challenging due to the often-low activity, level of expression and stability of P450 biocatalysts. Despite these challenges they are increasingly desirable as recombinant biocatalysts, particularly for the production of drug metabolites. Diclofenac is a widely used anti-inflammatory drug that is persistent in the environment along with the 4'- and 5-hydroxy metabolites. Here we have used the self-sufficient P450 RhF (CYP116B2) from Rhodococcus sp. in a whole cell system to reproducibly catalyse the highly regioselective oxidation of diclofenac to 5-hydroxydiclofenac. The product is a human metabolite and as such is an important standard for environmental and toxicological analysis. Furthermore, access to significant quantities of 5-hydroxydiclofenac has allowed us to demonstrate further oxidative degradation to the toxic quinoneimine product. Our studies demonstrate the potential for gram-scale production of human drug metabolites through recombinant whole cell biocatalysis.
\end{abstract}




\section{Introduction}

The occurrence of pharmaceutically active compounds and their metabolites in the environment, in particular in aquatic systems, is of increasing concern with the continuing growth of the global pharmaceutical industry [1,2]. Diclofenac (1) is one such compound that has been detected in many aquatic environments, with significant levels being found in wastewater samples [1]. It is a widely used non-steroidal anti-inflammatory drug (NSAID), which is the active ingredient in Cataflam $₫$, Voltaren $®$ and Zipsor $₫$ and is also used extensively in veterinary medicine. The increasing persistence of diclofenac (1) and its hydroxyl derivatives 4'-hydroxydiclofenac (2) and 5-hydroxydiclofenac (3) in the environment is attributable to their low biodegradability. Consequently, conventional wastewater treatment plants are ineffective at removing 1-3 from the influent, in contrast to most other pharmaceutical waste products [3].

Pharmaceutical research and development requires assessment of the bioavailability, toxicity and metabolic fate of potential new drugs. Cytochrome P450 enzymes (CYPs or P450s) catalyse a range of synthetically challenging oxidation reactions and play a vital role in the metabolism of potentially toxic endogenous and exogenous chemicals [4]. As such, this family of enzymes are important tools in drug metabolism and pharmacokinetic studies $[4,5]$. The synthesis and evaluation of drug metabolites is not only important in drug development but their preparation is also necessary for use as standards in environmental analysis.

Diclofenac metabolites with hydroxylation at the 4' (2) and 5 (3) positions are the most commonly detected in the environment $[6,7]$ (Scheme 1). However, they are difficult to synthesise since chemical oxidation of non-activated $\mathrm{C}-\mathrm{H}$ bonds can lead to the formation of complex product mixtures. As a result, they are currently expensive to purchase with limited commercial availability. Enzymes operate under ambient 
temperatures and with high levels of regio- and stereoselectivity, as such enzymatic methods for the synthesis of drug metabolites are highly desirable.

The bacterial P450 BM3 (CYP102A1) from Bacillus megaterium is catalytically selfsufficient - with the haem and reductase domains present on a single polypeptide strand and has been the subject of extensive engineering studies [8-10]. The double mutant D251G/Q307H has been evolved to produce $2[11,12]$ and a quadruple mutant has been shown to produce a mixture of 2 and 3 [13]. However, there is currently no selective biocatalytic route to 3. 5-hydroxydiclofenac (3) and its subsequent oxidative metabolite, the quinoneimine $\mathbf{4}$ are of particular interest for toxicology studies, since they have been shown to provide an antigenic determinant for immune cell activation in mice [14]. Chemical synthesis of $\mathbf{3}$ is lengthy and has only been achieved on mg scale and with significant side-products [15]. 5-Hydroxydiclofenac (3) is therefore an excellent target for production from 1 using biocatalysis.

Biocatalysis offers highly regio- and stereoselective routes to target compounds under mild experimental conditions. Disadvantages to using biocatalysis include challenges associated with poor enzyme activity and/or stability, narrow substrate specificity, production cost of the biocatalyst and expensive cofactor requirements [1618]. These limitations are of concern for biocatalytic reactions involving single P450 monooxygenases, where few large scale (beyond mg) examples have been reported [1924]. Previous studies have typically used P450 expressing strains or eukaryotic P450s that require the addition of reductase partners $[25,26]$. Using 3 as the target compound our aim was to develop a robust and reliable $E$. coli whole cell biocatalytic system that can oxidise diclofenac with exquisite selectivity and high yield at high substrate concentrations using molecular oxygen. Development of such a system would make 5hydroxydiclofenac available for future toxicology studies and as a standard for environmental analysis. 


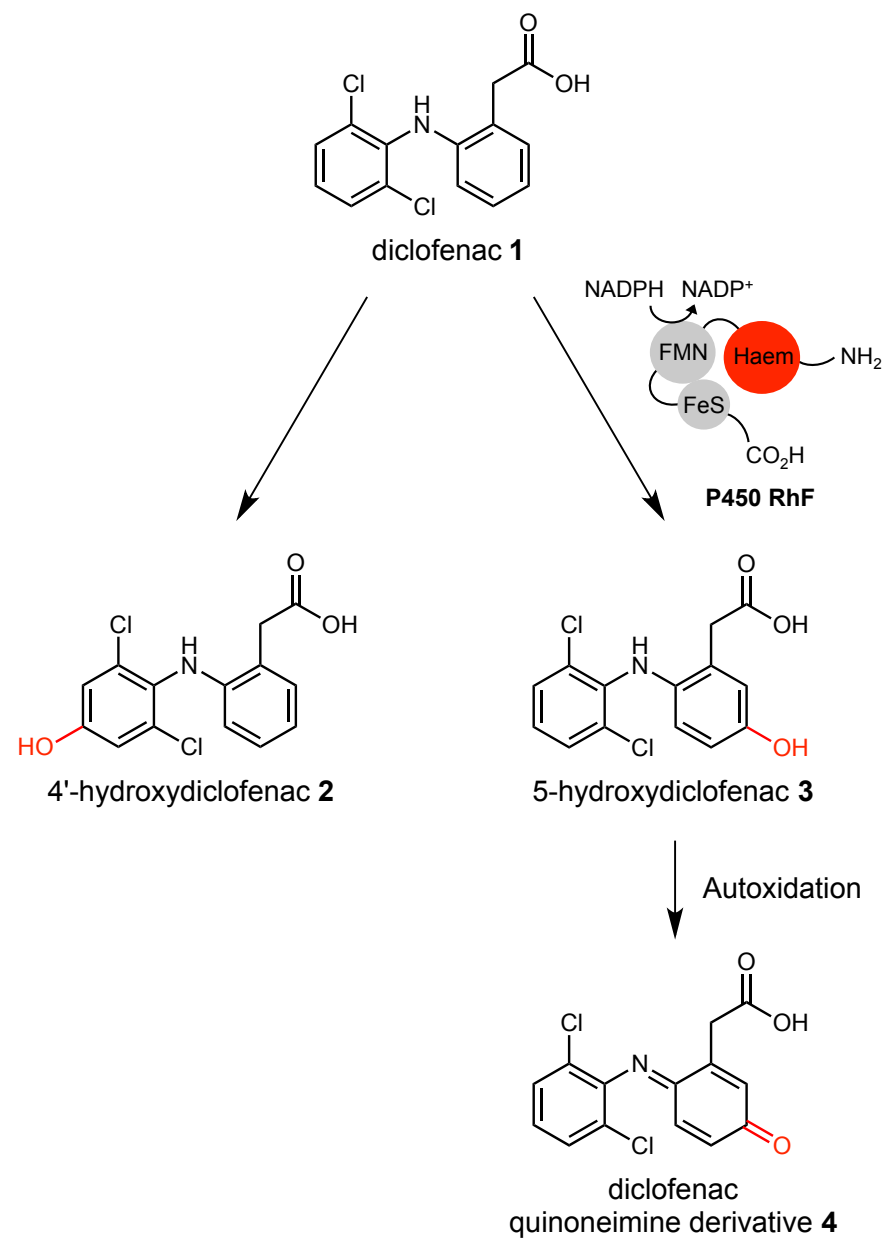

Scheme 1. Metabolites of diclofenac

\section{Materials and methods}

\subsection{Small/medium scale RhF expression}

The pET-YSBLIC vector (modified from the pET28a(+) vector) [27] containing the P450 RhF gene was transformed into E. coli BL21(DE3) cells and grown on LB agar supplemented with kanamycin $\left(50 \mu \mathrm{g} \mathrm{mL}^{-1}\right)$ and glucose $(0.4 \% \mathrm{w} / \mathrm{v})$. A starter culture was used to inoculate a larger volume of M9 media supplemented with glucose $(0.4 \%)$, $\mathrm{FeCl}_{3}(0.05 \%) \mathrm{MgSO}_{4}(1 \mathrm{mM})$ and $\mathrm{CaCl}_{2}(1 \mathrm{mM})$. The cells were grown to $\mathrm{OD}_{600} \sim 0.5$ then induced with IPTG $(0.4 \mathrm{mM})$ and 5-aminolevulinic acid (ALA) $(0.5 \mathrm{mM})$ and grown for a further 16 hours at $23^{\circ} \mathrm{C}$. 


\subsection{Fermentation procedure}

Fermentation experiments were carried out in $1 \mathrm{~L}$ or $5 \mathrm{~L}$ Multifors bioreactors (Infors AG, Bottmingen, Switzerland) containing either $0.8 \mathrm{~L}$ or $4 \mathrm{~L}$ of an enriched M9 medium (1\% glucose, 2x M9 ingredients). The plasmid pET-YSBLIC P450 RhF was freshly transformed in E. coli BL21(DE3) on LB-Agar plates supplemented with kanamycin (50 $\mu \mathrm{g} \mathrm{mL}^{-1}$ ). A single colony was used to inoculate M9 medium (50 - $100 \mathrm{~mL}$ ). After overnight incubation the preculture was used to inoculate the bioreactor with a starting $\mathrm{OD}_{600}$ of 0.05 . Cells were grown at $37^{\circ} \mathrm{C}, 800 \mathrm{rpm}$ stirrer speed and $2 \mathrm{vvm}$ (volumes of air per volume) aeration until an $\mathrm{OD}_{600}$ of $6.0-7.0$. The temperature was subsequently reduced to the expression temperature of $23^{\circ} \mathrm{C}$ before induction (for about one hour) and $\mathrm{MgSO}_{4}(1 \mathrm{mM})$, $\mathrm{CaCl}_{2}(0.3 \mathrm{mM})$ and $\left(\mathrm{NH}_{4}\right)_{2} \mathrm{HPO}_{4}\left(5 \mathrm{~g} \mathrm{~L}^{-1}\right)$ supplements were added. Expression of $\mathrm{P} 450$ $\mathrm{RhF}$ was started at an $\mathrm{OD}_{600}$ of approximately $9.0-10.0$ with the addition of IPTG, $\mathrm{FeSO}_{4}$ and 5-ALA (each $0.4 \mathrm{mM}$ ). Due to low initial glucose concentration (C-source shortage after $\mathrm{OD}_{600}$ of approximately 10.0 ) and to prevent high acetate concentrations during expression, a linear feeding strategy was used with a feeding solution containing glycerol. The nutrient solution was calculated to supplement the cells with one equivalent of M9 salts and glycerol $\left(40 \mathrm{~g} \mathrm{~L}^{-1}\right)$ over the expression period. A pH of 7.4 was maintained with $\mathrm{NH}_{4} \mathrm{OH}(25 \% \mathrm{v} / \mathrm{v})$ and $\mathrm{H}_{3} \mathrm{PO}_{4}(10 \% \mathrm{v} / \mathrm{v})$ during the process. $\mathrm{P} 450 \mathrm{RhF}$ was expressed at $23^{\circ} \mathrm{C}$ for approximately $13 \mathrm{~h}$. Antifoam 204 was added in small amounts as needed.

The optical density was measured at $600 \mathrm{~nm}$ (spectrophotometer Ultrospec 3000, Amersham Pharmacia Biotech, Uppsala, Sweden). To determine the cell dry weight (cdw), samples ( $3 \times 2 \mathrm{~mL}$ ) were centrifuged for $2 \mathrm{~min}$ at $20800 \times \mathrm{g}$ (5417R, Eppendorf AG, Hamburg, Germany), the supernatant was removed and the samples were incubated at $70^{\circ} \mathrm{C}$ until dry (approximately $24 \mathrm{~h}$ ). At the same time additional samples (8 $\mathrm{mL}$ ) were used to generate cell lysates of $\mathrm{P} 450 \mathrm{RhF}$ by sonication. The $\mathrm{P} 450$ concentration was 
determined by CO difference spectroscopy using an extinction coefficient of $\varepsilon=91 \mathrm{mM}^{-1}$ $\mathrm{cm}^{-1}$ for the calculation [28]. To compare different expression levels, the amount of active soluble P450 enzyme was related to the cdw.

\subsection{Scale-up of biotransformations for the production of 5-hydroxydiclofenac}

Following P450 RhF expression the biotransformations were carried out with growing cells in the same bioreactor or with resting cells in a $1 \mathrm{~L}$ Multifors bioreactor. For the latter approach the cells were centrifuged for $15 \mathrm{~min}$ at $4000 \mathrm{x}$ g (Avanti J-26S XP, Beckman Coulter, Brea, USA) and re-suspended to $0.05-0.075 \mathrm{~g}_{\mathrm{cww}} \mathrm{mL}^{-1}$ in $\mathrm{KPi}$ buffer $(100 \mathrm{mM}$, pH 7.5) supplemented with glucose $(30 \mathrm{mM})$ and kanamycin $\left(30 \mu \mathrm{gL}^{-1}\right)$. The biotransformation was performed at $20^{\circ} \mathrm{C}$ and $400 \mathrm{rpm}$. Diclofenac $\left(0.3 \mathrm{~g} \mathrm{~L}^{-1}\right.$ from a $75 \mathrm{~g} \mathrm{~L}^{-}$ ${ }^{1}$ stock solution in DMSO) was added to start the reaction and additional substrate $\left(0.1 \mathrm{~g} \mathrm{~L}^{-}\right.$ 1) was fed after 8 and $23 \mathrm{~h}$ (Table 1). Samples were taken at different time points and analysed by HPLC (Figure 1). To determine the product concentration a standard curve (from 0.0078 to $2.0 \mathrm{~g} \mathrm{~L}^{-1}$ ) was applied using the purified 5-hydroxydiclofenac powder dissolved in M9 medium.

\subsection{Analytical HPLC}

Analytical reversed phase HPLC (Figure S1) was performed on an Agilent system (Santa Clara, CA, USA) equipped with a G1311A quaternary pump, a HIP ALS G1367A auto sampler and a G1315D DAD detector. A Phenomenex Kinetex ${ }^{\circledR} \mathrm{C}_{18}$ column $(150$ x 2.1 mm; $2.6 \mu \mathrm{m}, 100 \AA$ ) at $40^{\circ} \mathrm{C}$ was used for separations. Samples were eluted using a binary gradient solvent system of $\mathrm{H}_{2} \mathrm{O}(\mathrm{A}) / \mathrm{MeCN}(\mathrm{B})+0.1 \%(\mathrm{v} / \mathrm{v})$ formic acid with detection at 272 nm, Bw 4 Ref. 360 nm, Bw 50. Elution conditions and flow gradient are given in Table S3. 


\subsection{Isolation of diclofenac metabolites}

For semi-preparative HPLC $4 \mathrm{~L}$ of fermentation broth was concentrated to $400 \mathrm{~mL}$ and extracted with ethyl acetate $(2 \times 400 \mathrm{~mL})$. The organic phases were combined and reduced to dryness. The solid residue was dissolved in acetonitrile $(10 \mathrm{~mL})$ and stored at $4^{\circ} \mathrm{C}$. Reversed phase semi-preparative HPLC was performed on an Agilent system (Santa Clara, CA, USA) equipped with a G1311A quaternary pump, a HIP ALS G1367B auto sampler (400 $\mu \mathrm{L}$ loop), a G1315D DAD detector and an analytical fraction collector G1364C. Separations were carried out at ambient temperature using a Trentec Reprosil ${ }^{\circledR} 100-5 \mathrm{C}_{18}$ column $(250$ x $20 \mathrm{~mm} ; 5 \mu \mathrm{m}$ ). Samples were eluted with a binary gradient solvent system of $\mathrm{H}_{2} \mathrm{O}$ $(\mathrm{A}) / \mathrm{MeCN}(\mathrm{B})+0.1 \%(\mathrm{v} / \mathrm{v})$ formic acid. Elution, flow gradient and fraction collection time are shown in Tables S4 and S5. The product fractions were combined and the solution was concentrated under reduced pressure. The remaining aqueous phase was extracted with methyl tert-butyl ether (1:3). The organic phase was separated and concentrated under reduced pressure. Samples were dried overnight under an $\mathrm{N}_{2}$ stream.

For flash chromatography, an equal volume of ethyl acetate was added to the biotransformation reaction solution. The organic phase was separated then concentrated under reduced pressure. Flash chromatography of the residue on silica with a mobile phase of cyclohexane/ethyl acetate (3:1) gave separation of the metabolites from unreacted diclofenac. The product was concentrated under reduced pressure then dried under $\mathrm{N}_{2}$ and stored below $4^{\circ} \mathrm{C}$.

\subsection{Metabolite characterisation}

5-Hydroxydiclofenac (3) was analysed by LC-MS and FT-IR, (Figure S2-S4). Mass spectra were measured by electrospray ionization mass spectrometry (HPLC/ESI-MS) in positive ion mode: An Agilent 1260 HPLC (Agilent, Santa Clara, CA, USA) equipped with single quad ESI-MS was used for the LCMS analysis and a Phenomenex Kinetex $\mathrm{C}_{18}$ column $(150 \times 2.6$ 
$\mathrm{mm} ; 1.8 \mu \mathrm{m}$ ) used for chromatographic separations. A binary gradient of $\mathrm{MeCN}$ and $\mathrm{H}_{2} \mathrm{O}+$ $0.1 \%(\mathrm{v} / \mathrm{v})$ formic acid was used at a flow rate of $0.2 \mathrm{~mL} \mathrm{~min}^{-1}$ at $40^{\circ} \mathrm{C}$ and a detection wavelength of $272 \mathrm{~nm}$. MS parameters: ESI ionization; scan m/z 80 - 400; drying gas temperature $350^{\circ} \mathrm{C}$; drying gas flow $9.0 \mathrm{~L} \mathrm{~min}^{-1}$; nebulizer pressure $35 \mathrm{psi}$; Vcap $+3000 \mathrm{~V}$; fragmentation voltage $70 \mathrm{eV}$. FT-IR-spectra were recorded with a FT-IR spectrometer (Bruker, Vector 22, equipped with a MKII golden gate single reflection diamond ATRSystem). MS: m/z (ESI+) 312.0 [M+H]+; IR: 3340 (NH), $3340-2840 \mathrm{~cm}^{-1}(\mathrm{OH}), 2915.6 \mathrm{~cm}^{-1}$ (COOH), $1687.8 \mathrm{~cm}^{-1}(\mathrm{C}=0)$ for 3. MS: $\mathrm{m} / \mathrm{z}(\mathrm{ESI}+) 310.0[\mathrm{M}+\mathrm{H}]^{+}$for 4.

${ }^{1} \mathrm{H}$ and ${ }^{13} \mathrm{C}$ 1D and 2D nuclear magnetic resonance (NMR) spectra for $\mathbf{3}$ and $\mathbf{4}$ were recorded on a Bruker Avance 500 spectrometer operating at $500 \mathrm{MHz}$ and $126 \mathrm{MHz}$ respectively (Figure S5 - S8). 5-Hydroxydiclofenac (3); ${ }^{1} \mathrm{H}-\mathrm{NMR}\left(500 \mathrm{MHz}, \mathrm{CD}_{3} \mathrm{OD}, 35^{\circ} \mathrm{C}\right.$, TMS): $\delta$ ppm $3.71\left(\mathrm{~s}, 2 \mathrm{H} ; \mathrm{CH}_{2}\right), 6.37(\mathrm{~d}, J=8.8 \mathrm{~Hz}, 1 \mathrm{H} ; 3-\mathrm{H}), 6.55(\mathrm{dd}, J=8.8,2.5 \mathrm{~Hz}, 1 \mathrm{H} ; 4-$ H), $6.72(\mathrm{~d}, J=2.5 \mathrm{~Hz}, 1 \mathrm{H} ; 6-\mathrm{H}), 6.96\left(\mathrm{t}, J=7.8 \mathrm{~Hz}, 1 \mathrm{H} ; 4^{\prime}-\mathrm{H}\right)$ and $7.34\left(\mathrm{~d}, J=7.8 \mathrm{~Hz} 2 \mathrm{H} ; 3^{\prime}\right.$ and $\left.5^{\prime}-\mathrm{H}\right) ;{ }^{13} \mathrm{C}-\mathrm{NMR}\left(126 \mathrm{MHz}, \mathrm{CD}_{3} \mathrm{OD}, 35^{\circ} \mathrm{C}, \mathrm{TMS}\right) \delta \mathrm{ppm} 39.2\left(\underline{\mathrm{CH}}_{2}\right), 115.3$ (ArCh-4), 118.3

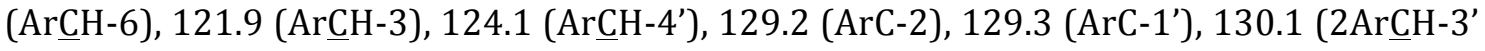
and 5'), 136.4 (ArC-1), $140.5(2 \underline{\mathrm{CCl}}), 154.1(\underline{\mathrm{COH}}), 175.8(\underline{\mathrm{COOH}})$.

The quinoneimine derivative $\mathbf{4}$ of diclofenac was prepared from 5hydroxydiclofenac (3) following a previously reported procedure using silver (I) nitrate instead of silver (I) oxide [14]. Quinoneimine derivative $4{ }^{1} \mathrm{H}-\mathrm{NMR}\left(500 \mathrm{MHz}, \mathrm{C}_{2} \mathrm{D}_{6} \mathrm{OS}\right.$, $\left.35^{\circ} \mathrm{C}, \mathrm{TMS}\right): \delta$ ppm $3.69\left(\mathrm{~s}, 2 \mathrm{H} ; \mathrm{C}_{2}\right), 6.59(\mathrm{dd}, J=10.1,2.5 \mathrm{~Hz}, 1 \mathrm{H} ; 4-\mathrm{H}), 6.74(\mathrm{~d}, J=10.1 \mathrm{~Hz}$, 1H; 3-H), $6.80(\mathrm{~d}, J=2.5 \mathrm{~Hz}, 1 \mathrm{H} ; 6-\mathrm{H}), 7.25\left(\mathrm{t}, J=8.2 \mathrm{~Hz}, 1 \mathrm{H} ; 4^{\prime}-\mathrm{H}\right)$ and $7.58(\mathrm{~d}, J=7.6 \mathrm{~Hz}$, $2 \mathrm{H} ; 3^{\prime}$ and $\left.5^{\prime}-\mathrm{H}\right) ;{ }^{13} \mathrm{C}-\mathrm{NMR}\left(126 \mathrm{MHz}, \mathrm{C}_{2} \mathrm{D}_{6} \mathrm{OS}, 35^{\circ} \mathrm{C}\right.$, TMS $) \delta$ ppm $36.3\left(\underline{\mathrm{CH}}_{2}\right), 123.1(\mathrm{ArC})$, 126.6 (ArC), 128.6 (ArC), 129.1 (ArC), 133.1 (ArC), 133.5 (ArC), 143.4 (ArC-1'), 145.1 (ArC-1), $160.4($ ArC-2), $170.6(\underline{\mathrm{COOH}}), 186.9(\underline{\mathrm{C}}=0)$. Analysis by analytical HPLC confirmed the synthetic quinoneimine $\mathbf{4}$ had a matching identical retention time to the oxidised side product observed during the biotransformations. 


\section{Results and Discussion}

\subsection{Identification of the selective 5-hydroxylation of diclofenac by CYP116B2}

The self-sufficient nature of bacterial P450s provides an attractive incentive for their use in biocatalysis over their mammalian counterparts, which require the co-expression of redox partners. A screen of available recombinant P450 monooxygenases in our laboratories was conducted to find a suitable biocatalyst for the hydroxylation of the antiinflammatory drug diclofenac (Page S2 and Table S1, Supporting Information). The native P450 RhF (CYP116B2) from Rhodococcus sp. strain NCIMB 9784 was identified as a suitable candidate. $\mathrm{P} 450 \mathrm{RhF}$ is a self-sufficient enzyme with a novel fused flavin mononucleotide (FMN) and 2Fe-2S ferredoxin containing reductase domain $[29,30]$ (Scheme 1).

Small and medium scale reactions $(0.5-160 \mathrm{~mL})$ were conducted using P450 RhF in a whole cell system with a diclofenac substrate concentration of up to $2 \mathrm{mM}$. Conversions of up to $60-70 \%$ were monitored using reverse-phase HPLC. Interestingly, highly selective hydroxylation at the 5-position was observed, as confirmed by mass spectrometry and NMR spectroscopy of the isolated product (Figure S3 and S5-S7, Supporting Information). Production of product at larger scale required the transfer from flask experiments to bioreactors. During previous studies we had encountered significant issues with construct stability primarily resulting from proteolytic degradation of recombinant P450 monooxygenases [30, 31], which often required fresh transformation of cells with P450 containing plasmids. The stability of plasmids, especially those baring genes of toxic proteins like P450s, is thought to be enhanced when freshly transformed since the percentage of plasmid baring BL21(DE3) is observed to decrease over time, most notably following induction [32]. It was therefore important to establish that the present 
system was stable and reproducible to enable implementation of an efficient whole cell process.

\subsection{Optimisation and scale up of diclofenac biotransformations}

Expression of P450 RhF was optimised in a buffered M9 medium with glycerol feeding during the expression period (Page S2, Supporting Information), to achieve an average biocatalyst concentration of $33 \mathrm{mg}$ active $\mathrm{P} 450 \mathrm{RhF} \mathrm{gcdw}^{-1}$. This is comparable with values from the optimised high-yield production of P450 BM3 [33]. Expression at lower temperatures $\left(<25^{\circ} \mathrm{C}\right)$ increased yield of active enzyme giving the highest activity and productivity during biotransformations.

Initial biotransformations were conducted using varying glycerol and substrate feeding strategies (Table S2, Supporting Information). Biotransformations using resting cells were done with substrate added at the start of the reaction (R3 and R4, Table S2), or fed at time points throughout (R1 and R2, Table S2). The influence of feeding glycerol as a carbon source during the biotransformation was also assessed and found to be detrimental to activity. The use of a substrate feeding strategy gave the best productivity with $20 \mathrm{mg} \mathrm{L}^{-1} \mathrm{~h}^{-1}$, compared to $8.9 \mathrm{mg} \mathrm{L}^{-1} \mathrm{~h}^{-1}$ when diclofenac was added at a single point at the beginning of the reaction. Furthermore, the biocatalyst was shown to have good stability during the fermentation by displaying high residual activity after 24 hours. Biotransformations with growing cells were conducted in triplicate with different cell clones and whole cell suspension with high reproducibility. P450 RhF expression was broadly similar between starter colonies.

Using results from the initial biotransformations a substrate feeding strategy was applied to both growing and resting cells to provide a direct comparison (Table 1, Figure 1). Biotransformations were conducted in duplicate and significant differences in activity were observed between the use of growing and resting cells. In addition, with the use of 
growing cells it was observed that there was some absorption of diclofenac by the biomass, such that the measured diclofenac concentration in the fermentation media was lower than the actual amount added (Figure 1A). This was observed to a lesser extent with resting cells and did not reduce the availability of the substrate for catalysis as evidenced from the concentrations of 1, 3 and 4 measured just prior to the $8 \mathrm{~h}$ feed (Figure 1B). In biotransformations with growing cells an average maximum specific activity of $0.024 \mathrm{mg}_{5}$ он DCF $\mathrm{L}^{-1} \mathrm{~h}^{-1} \mathrm{mg}_{\mathrm{P} 450^{-1}}$ compared to $0.071 \mathrm{mg}_{5-\mathrm{OH} \text { DCF }} \mathrm{L}^{-1} \mathrm{~h}^{-1} \mathrm{mg}_{\mathrm{P} 450^{-1}}$ with resting cells was observed. After $30.5 \mathrm{~h}$ a product concentration of $0.36 \mathrm{~g} \mathrm{~L}^{-1}$ and an average productivity of $11.7 \mathrm{mg} \mathrm{L}^{-1} \mathrm{~h}^{-1}$ was achieved using $\mathrm{P} 450 \mathrm{RhF}$ in resting cells. This is a great improvement on growing cells where the product concentration and the productivity were $0.08 \mathrm{~g} \mathrm{~L}^{-1}$ and $2.6 \mathrm{mg} \mathrm{L}^{-1} \mathrm{~h}^{-1}$ respectively under equal bioreactor conditions and similar optical densities. P450 RhF constructs in the corresponding cell lysates were analysed by CO difference spectroscopy using excess NADPH as the reducing agent (Page S3, Supporting Information) [34, 35]. This spectrum was compared to a traditional P450 CO difference spectrum and showed equivalent absorbance at $450 \mathrm{~nm}$, indicating correct fusion and function of the election delivering partners with the haem domain of $\mathrm{P} 450 \mathrm{RhF}$ (Table S6, Supporting Information). 
Table 1. Whole-cell activities of $\mathrm{P} 450 \mathrm{RhF}$ with growing and resting cells.a)

\begin{tabular}{|c|c|c|c|c|c|c|}
\hline Culture & $\begin{array}{l}\text { P450 } \\
\text { content }{ }^{b)} \\
\left(\frac{\text { g }_{P 450}}{g_{c d w}}\right)\end{array}$ & $\begin{array}{l}\text { Maximum } \\
\text { concentration } \\
\left(\frac{g_{5-O H ~ D C F}}{L}\right)\end{array}$ & $\begin{array}{l}\text { Maximum specific } \\
\text { activityc) } \\
\left(\frac{\mathbf{m g}_{5-0 H ~ D C F}}{\mathrm{~L} * \mathbf{h} * \mathbf{m g} \text { P450 }}\right)\end{array}$ & $\begin{array}{l}\text { Productivityd) } \\
\left(\frac{\text { mg }_{5-0 H ~ D C F}}{\mathbf{L} * \mathbf{h}}\right)\end{array}$ & $\begin{array}{l}\text { Total cdw } \\
\text { (g) }\end{array}$ & $\begin{array}{l}\text { Total } \\
\text { Product } \\
\text { (mg) }\end{array}$ \\
\hline $\begin{array}{l}\text { Growing } \\
\text { cells: } \\
\text { Clone } 1\end{array}$ & 22.5 & 0.072 & 0.024 & 2.4 & 7.5 & 57.5 \\
\hline $\begin{array}{l}\text { Growing } \\
\text { cells: } \\
\text { Clone } 2\end{array}$ & 24.5 & 0.085 & 0.023 & 2.8 & 7.3 & 67.7 \\
\hline $\begin{array}{l}\text { Resting } \\
\text { cells: } \\
\text { Clone } 1\end{array}$ & 27.0 & 0.370 & 0.077 & 12.2 & 7.9 & 235.1 \\
\hline $\begin{array}{l}\text { Resting } \\
\text { cells: } \\
\text { Clone } 2\end{array}$ & 28.5 & 0.344 & 0.064 & 11.3 & 8.0 & 221.7 \\
\hline
\end{tabular}

a) Precultures of two clones were used to inoculate four $1 \mathrm{~L}$ bioreactors (800 $\mathrm{mL}$ working volume).

b) Measured by CO difference spectroscopy.

c) Rates calculated based on time points of highest product increase per hour.

d) Productivity calculated over the entire process time of 30.5 hours.

The levels of NADPH produced by E. coli itself (approximately $0.2 \mathrm{mM}$ ) are catabolically insufficient. Sufficient NADPH availability and an associated adequate redox balance within the cells can be a limiting factor for high enzymatic activity rates [36, 37]. A benefit of using resting cells over growing cells is the ease with which media and buffer can be exchanged. Here the used expression medium was replaced with buffer and supplemented with glucose. The use of non-growing or glucose-limited cells can lead to an excess of NADPH formation through a favoured equilibrium in the co-factor recycling system [38]. In contrast, glycerol feeding during biotransformations with growing cells would not enhance NADPH production and could be a factor limiting P450 RhF activity 
resulting in a lower 5-hydroxydiclofenac (3) formation rate (Table S2, Supporting Information).
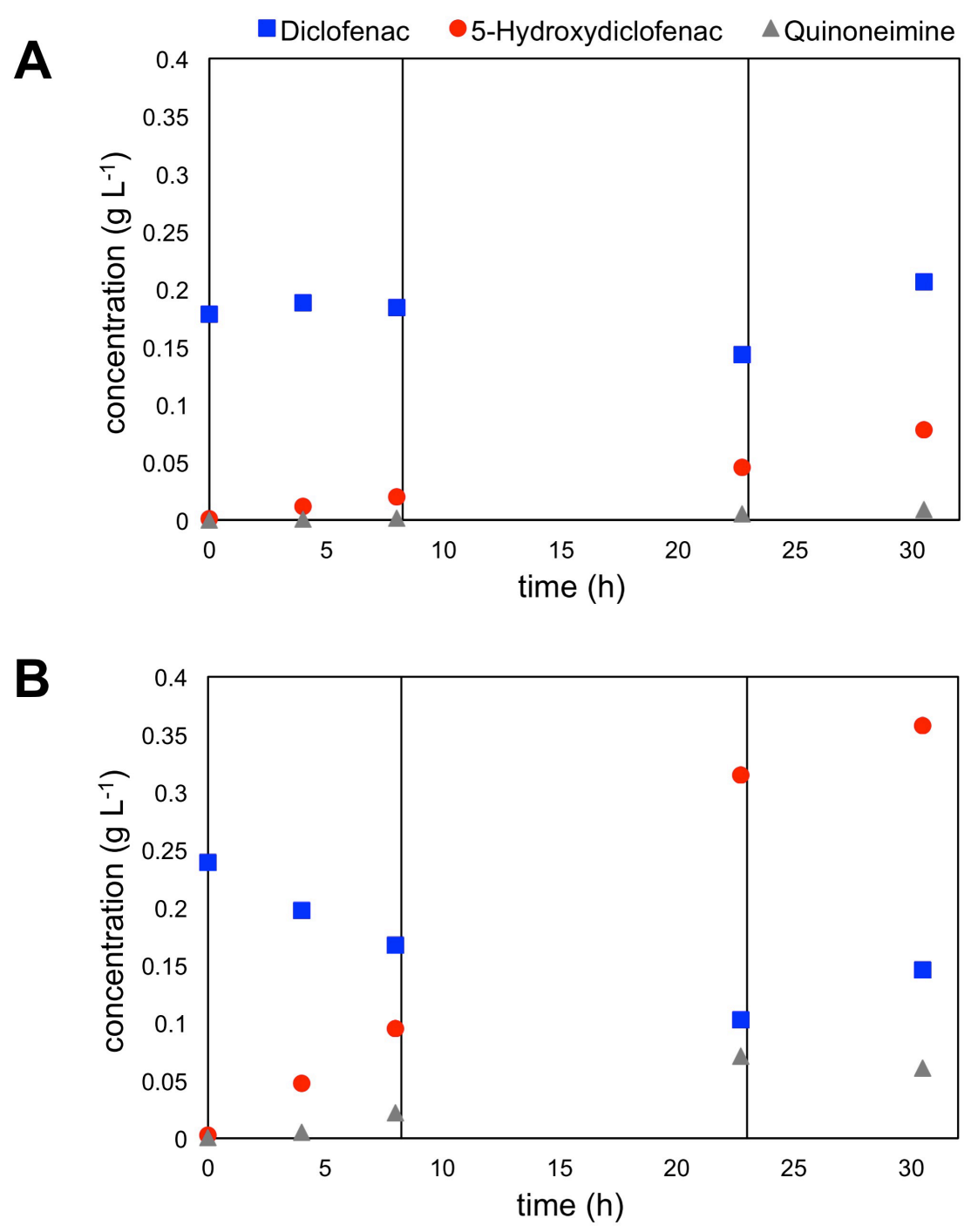

Figure 1. Time point assays showing the RhF catalysed conversion of diclofenac (feeding indicated by solid vertical lines (-)) to 5-hydroxydiclofenac (3) and formation of the quinoneimine (4) derivative with A) growing cells and B) resting cells

Overall the implementation of a whole cell system has many benefits over the use of lysates and purified enzymes. The major benefits include i) the need for auxiliary 
electron delivering partners is negated, ii) reduced sample handling time and associated expenses and iii) higher tolerance for protein instability due to expression and application in a single host. The latter aspect is particularly important when considering the application of P450 RhF. During this study attempts were made to purify the enzyme by IMAC for further reaction characterisation. However, the purified construct was largely inactive. Typical CO difference spectroscopy (obtained using sodium dithionite) showed a prominent peak at $450 \mathrm{~nm}$ but when NADPH was used as the reductant, the peak at $450 \mathrm{~nm}$ was minimal (Page S3 and Table S6, Supporting Information). These results, combined with SDS-PAGE analysis that shows purification of the full-length protein (Figure S9, Supporting Information), suggest that the haem domain itself is functional, however the electron transport through the fusion protein is severely hindered. This is likely due to instability of the FMN-FeS reductase domains. Conversely as mentioned previously, when the same experiments were conducted using freshly lysed cells the fusion construct was shown to be intact and functional. These results further highlight the benefit of using a whole cell system for P450 catalysed bio-oxidations and especially in this case for the P450 RhF catalysed oxidation of diclofenac.

\subsection{Autoxidation of 5-hydroxydiclofenac (3) to the quinoneimine derivative 4}

During the HPLC analysis of diclofenac (1) hydroxylation, an additional peak with retention time close to the 5-hydroxy derivative $\mathbf{3}$ was detected (Figure S1, Supporting Information). The ratio between $\mathbf{3}$ and the new peak was observed to increase over time. Analysis by LC-MS and NMR spectroscopy identified the peak as a quinoneimine derivative 4 of diclofenac (Figure S3 and S8, Supporting Information). Formation of $\mathbf{4}$ has been observed previously in diclofenac metabolism studies [39, 40], with some reporting that its formation is enzyme catalysed [40]. Here we can exclude an over-oxidation by the enzyme itself since quinoneimine $\mathbf{4}$ formation was not enhanced in the presence of P450 
RhF with NADPH and a cofactor recycling system compared to lysate from E. coli containing pET28a(+) empty plasmid (data not shown). Experiments with purified 5hydroxydiclofenac (3) show that the quinoneimine $\mathbf{4}$ formation takes place by an autoxidation reaction influenced by increasing temperature and solvent (Figure 2). While purified 5-hydroxydiclofenac 3 powder is relatively stable at $4^{\circ} \mathrm{C}$, the oxidation starts within a short time upon dissolving in aqueous solution. Using a salt containing medium (e.g. M9 medium, $\mathrm{CaCl}_{2}$ or $\mathrm{MgSO}_{4}$ containing aqueous solutions) the quinoneimine 4 formation increased significantly. The observed spontaneous formation of this derivative 4 could have environmental implications due to the potentially toxic nature of this highly reactive compound [14]. Purified 5-hydroxydiclofenac (3) should be kept at low temperature under dry conditions to prevent formation of 4.

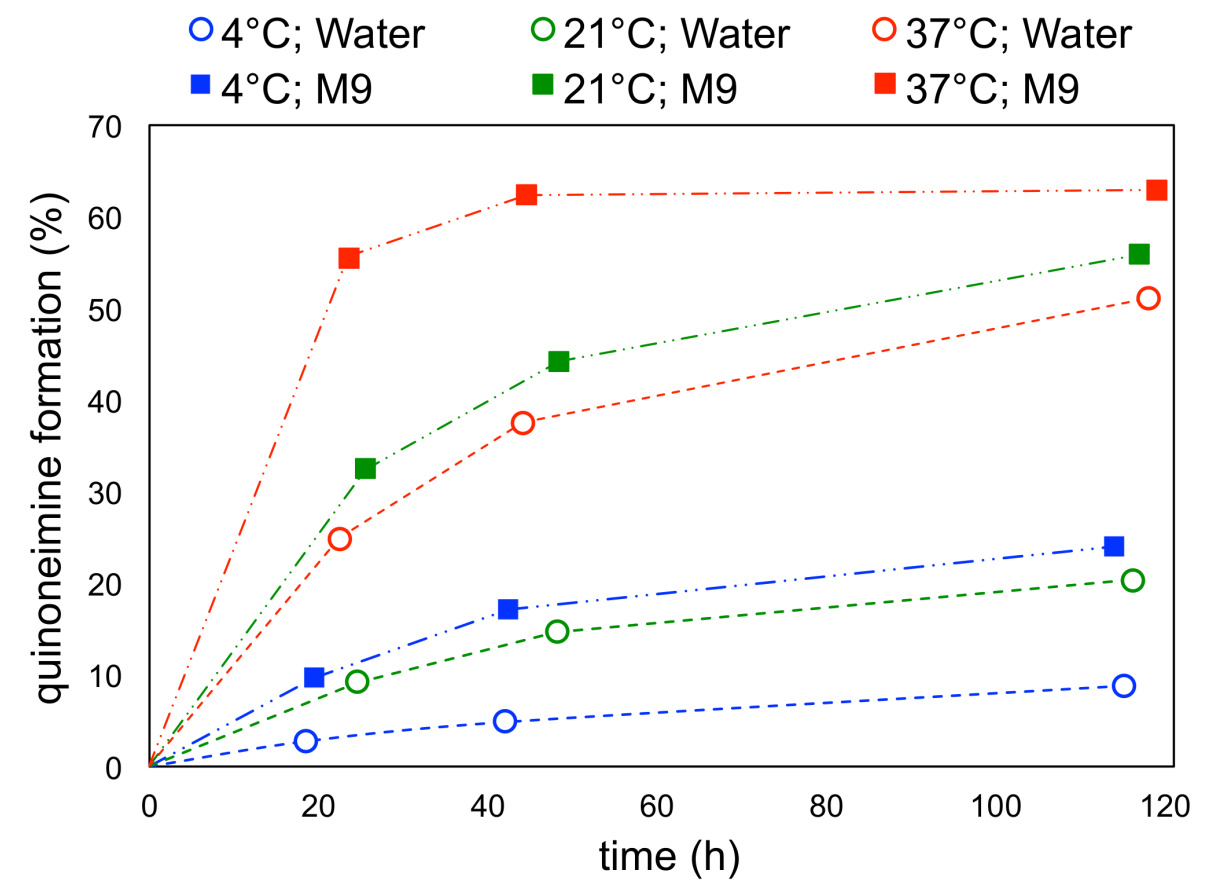

Figure 2. Quinoneimine 4 formation from 5-hydroxydiclofenac (3) under different conditions and at different time points. Purified 5-hydroxydiclofenac (0.3 $\left.\mathrm{g} \mathrm{L}^{-1}\right)$ was 
dissolved in $\mathrm{M} 9$ medium or in $\mathrm{ddH}_{2} \mathrm{O}$ and incubated at $4^{\circ} \mathrm{C}, 21^{\circ} \mathrm{C}$ or $37^{\circ} \mathrm{C}$. The resulting quinoneimine production was monitored by HPLC.

\subsection{Isolation of 5-Hydroxydiclofenac}

The 5-hydroxydiclofenac metabolite (3) was purified for NMR characterisation (Figure S5-S7, Supporting Information) by preparative HPLC. Biotransformations with resting cells gave yields of between 220-240 mg purified 5-hydroxydiclofenac (3). The target metabolite $\mathbf{3}$ can be more readily separated from unconverted diclofenac (1) through silica column chromatography (Section 2.5). Purification by flash chromatography is a simple method for purification of the metabolite $\mathbf{3}$ and would be suitable for downstream processing of larger scale fermentations.

\section{Concluding Remarks}

In summary, we have presented a biocatalytic route that gives access to 5hydroxydiclofenac (3) using a cheap and easily available whole cell system with recombinant $\mathrm{P} 450 \mathrm{RhF}$ (CYP116B2) expression, making it available as a laboratory standard for toxicity studies and analysis of environmental samples. We have scaled up the reaction to produce the metabolite reproducibly, with high regioselectivity and in good yield (>220 mg on $0.8 \mathrm{~L}$ scale). We have also demonstrated the potential for further scaleup of the reaction by fermentation. To our knowledge, this is the first report of the fermentation of a drug metabolite using whole cell reactions with heterologous expression of a self-sufficient P450 monooxygenase in E. coli. Non-enzymatic autoxidation to the quinoneimine derivative $\mathbf{4}$ has been observed at low levels in the whole cell reactions. Formation of this derivative increases over time, at elevated temperatures and in the presence of salts. This autoxidation should be considered in future investigations and particularly during analysis on the environmental fate of diclofenac. 


\section{Acknowledgement}

The research leading to these results has received funding from the European Union's Seventh Framework Programme for research, technological development and demonstration under grant agreements no 613849 (BIOOX) and 289217 (P4FIFTY). We also gratefully acknowledge financial support from the Landesgraduiertenförderung (LSFG) BadenWürttemberg. 


\section{References}

[1] Langford, K., Thomas, K. V., Input of selected human pharmaceutical metabolites into the Norwegian aquatic environment. J. Environ. Monit. 2011, 13, 416-421.

[2] Richardson, S. D., Ternes, T. A., Water analysis: Emerging contaminants and current issues. Anal. Chem. 2014, 86, 2813-2848.

[3] Martin, J., Camacho-Munoz, D., Santos, J. L., Aparicio, I., Alonso, E., Occurrence of pharmaceutical compounds in wastewater and sludge from wastewater treatment plants: Removal and ecotoxicological impact of wastewater discharges and sludge disposal. J. Hazard. Mater. 2012, 239-240, 40-47.

[4] Guengerich, F. P., Cytochrome P450s and other enzymes in drug metabolism and toxicity. The AAPS Journal 2006, 8, E101-E111.

[5] Zhang, K., Shafer, B. M., Demars, M. D., Stern, H. A., Fasan, R., Controlled oxidation of remote sp3 $\mathrm{C}-\mathrm{H}$ bonds in artemisinin via P450 catalysts with fine-tuned regio- and stereoselectivity. J. Am. Chem. Soc. 2012, 134, 18695-18704.

[6] Osorio, V., Imbert-Bouchard, M., Zonja, B., Abad, J.-L., et al., Simultaneous determination of diclofenac, its human metabolites and microbial nitration/nitrosation transformation products in wastewaters by liquid chromatography/quadrupole-linear ion trap mass spectrometry. J. Chromatogr. A 2014, 1347, 63-71.

[7] Scheurell, M., Franke, S., Shah, R. M., Huehnerfuss, H., Occurrence of diclofenac and its metabolites in surface water and effluent samples from Karachi, Pakistan. Chemosphere $2009,77,870-876$.

[8] Landwehr, M., Hochrein, L., Otey, C. R., Kasrayan, A., et al., Enantioselective $\alpha$ hydroxylation of 2-arylacetic acid derivatives and buspirone catalyzed by engineered cytochrome P450 BM-3. J. Am. Chem. Soc. 2006, 128, 6058-6059. 
[9] Kille, S., Zilly, F. E., Acevedo, J. P., Reetz, M. T., Regio- and stereoselectivity of P450catalysed hydroxylation of steroids controlled by laboratory evolution. Nat. Chem. 2011, 3, 738-743.

[10] Munro, A. W., Leys, D. G., McLean, K. J., Marshall, K. R., et al., P450 BM3: the very model of a modern flavocytochrome. Trends Biochem. Sci 2002, 27, 250-257.

[11] Tsotsou, G. E., Sideri, A., Goyal, A., Di Nardo, G., Gilardi, G., Identification of mutant Asp251Gly/Gln307His of cytochrome P450 BM3 for the generation of metabolites of diclofenac, ibuprofen and tolbutamide. Chem. - Eur. J. 2012, 18, 3582-3588.

[12] Di Nardo, G., Dell'Angelo, V., Catucci, G., Sadeghi, S. J., Gilardi, G., Subtle structural changes in the Asp251Gly/Gln307His P450 BM3 mutant responsible for new activity toward diclofenac, tolbutamide and ibuprofen. Arch. Biochem. Biophys. 2016, 602, 106-115. [13] Ren, X., Yorke, J. A., Taylor, E., Zhang, T., et al., Drug oxidation by cytochrome P450 BM3: metabolite synthesis and discovering new P450 reaction types. Chem. - Eur. J. 2015, $21,15039-15047$.

[14] Naisbitt, D. J., Sanderson, L. S., Meng, X., Stachulski, A. V., et al., Investigation of the immunogenicity of diclofenac and diclofenac metabolites. Toxicol. Lett. 2007, 168, 45-50.

[15] Kenny, J. R., Maggs, J. L., Meng, X., Sinnott, D., et al., Syntheses and characterization of the acyl glucuronide and hydroxy metabolites of diclofenac. J. Med. Chem. 2004, 47, 28162825.

[16] O'Reilly, E., Kohler, V., Flitsch, S. L., Turner, N. J., Cytochromes P450 as useful biocatalysts: Addressing the limitations. Chem. Commun. 2011, 47, 2490-2501.

[17] Lundemo, M. T., Woodley, J. M., Guidelines for development and implementation of biocatalytic P450 processes. Appl. Microbiol. Biotechnol. 2015, 99, 2465-2483.

[18] Bernhardt, R., Urlacher, V. B., Cytochromes P450 as promising catalysts for biotechnological application: chances and limitations. Appl. Microbiol. Biotechnol. 2014, 98, 6185-6203. 
[19] Schewe, H., Holtmann, D., Schrader, J., P450BM-3-catalyzed whole-cell biotransformation of $\alpha$-pinene with recombinant Escherichia coli in an aqueous-organic two-phase system. Appl. Microbiol. Biotechnol. 2009, 83, 849-857.

[20] Vail, R. B., Homann, M. J., Hanna, I., Zaks, A., Preparative synthesis of drug metabolites using human cytochrome P450s 3A4, 2C9 and 1A2 with NADPH-P450 reductase expressed in Escherichia coli. J. Ind. Microbiol. Biotechnol. 2005, 32, 67-74.

[21] Caswell, J. M., O'Neill, M., Taylor, S. J., Moody, T. S., Engineering and application of P450 monooxygenases in pharmaceutical and metabolite synthesis. Curr. Opin. Chem. Biol. $2013,17,271-275$.

[22] Sawayama, A. M., Chen, M. M., Kulanthaivel, P., Kuo, M. S., et al., A panel of cytochrome P450 BM3 variants to produce drug metabolites and diversify lead compounds. Chemistry $2009,15,11723-11729$.

[23] Kaluzna, I., Schmitges, T., Straatman, H., van Tegelen, D., et al., Enabling selective and sustainable P450 oxygenation technology. Production of 4-hydroxy- $\alpha$-isophorone on kilogram scale. Org. Process Res. Dev. 2016, 20, 814-819.

[24] Brummund, J., Muller, M., Schmitges, T., Kaluzna, I., et al., Process development for oxidations of hydrophobic compounds applying cytochrome P450 monooxygenases invitro. J. Biotechnol. 2016, 233, 143-150.

[25] Dragan, C. A., Peters, F. T., Bour, P., Schwaninger, A. E., et al., Convenient gram-scale metabolite synthesis by engineered fission yeast strains expressing functional human P450 systems. Appl. Biochem. Biotechnol. 2011, 163, 965-980.

[26] Paddon, C. J., Westfall, P. J., Pitera, D. J., Benjamin, K., et al., High-level semi-synthetic production of the potent antimalarial artemisinin. Nature 2013, 496, 528-532.

[27] O'Reilly, E., Corbett, M., Hussain, S., Kelly, P. P., et al., Substrate promiscuity of cytochrome P450 RhF. Catal. Sci. Technol. 2013, 3, 1490-1492. 
[28] Omura, T., Sato, R., The carbon monoxide-binding pigment of liver microsomes: I. evidence for its hemoprotein nature. J. Biol. Chem. 1964, 239, 2370-2378.

[29] Hunter, D. J. B., Roberts, G. A., Ost, T. W. B., White, J. H., et al., Analysis of the domain properties of the novel cytochrome P450 RhF. FEBS Lett. 2005, 579, 2215-2220.

[30] Roberts, G. A., Celik, A., Hunter, D. J. B., Ost, T. W. B., et al., A self-sufficient cytochrome P450 with a primary structural organization that includes a flavin domain and a [2Fe-2S] redox center. J. Biol. Chem. 2003, 278, 48914-48920.

[31] Sabbadin, F., Hyde, R., Robin, A., Hilgarth, E.-M., et al., LICRED: A versatile drop-in vector for rapid generation of redox-self-sufficient cytochrome P450s. ChemBioChem $2010,11,987-994$.

[32] Marisch, K., Bayer, K., Cserjan-Puschmann, M., Luchner, M., Striedner, G., Evaluation of three industrial Escherichia coli strains in fed-batch cultivations during high-level SOD protein production. Microb. Cell. Fact. 2013, 12.

[33] Pflug, S., Richter, S. M., Urlacher, V. B., Development of a fed-batch process for the production of the cytochrome P450 monooxygenase CYP102A1 from Bacillus megaterium in E. coli. J. Biotechnol. 2007, 129, 481-488.

[34] Khatri, Y., Hannemann, F., Ewen, K. M., Pistorius, D., et al., The CYPome of Sorangium cellulosum So ce56 and identification of CYP109D1 as a new fatty acid hydroxylase. Chem. Biol. 2010, 17, 1295-1305.

[35] Hoffmann, S. M., Weissenborn, M. J., Gricman, Ł., Notonier, S., et al., The impact of linker length on P450 fusion constructs: activity, stability and coupling. ChemCatChem $2016,8,1591-1597$.

[36] Walton, A. Z., Stewart, J. D., Understanding and improving NADPH-dependent reactions by nongrowing Escherichia coli cells. Biotechnol. Progr. 2004, 20, 403-411. 
[37] Fuhrer, T., Sauer, U., Different biochemical mechanisms ensure network-wide balancing of reducing equivalents in microbial metabolism. J. Bacteriol. 2009, 191, 21122121.

[38] Sauer, U., Canonaco, F., Heri, S., Perrenoud, A., Fischer, E., The soluble and membranebound transhydrogenases UdhA and PntAB have divergent functions in NADPH metabolism of Escherichia coli.J. Biol. Chem. 2004, 279, 6613-6619.

[39] Shen, S., Marchick, M. R., Davis, M. R., Doss, G. A., Pohl, L. R., Metabolic activation of diclofenac by human cytochrome P450 3A4: Role of 5-hydroxydiclofenac. Chem. Res. Toxicol. 1999, 12, 214-222.

[40] den Braver, M. W., den Braver-Sewradj, S. P., Vermeulen, N. P. E., Commandeur, J. N. M., Characterization of cytochrome P450 isoforms involved in sequential two-step bioactivation of diclofenac to reactive p-benzoquinone imines. Toxicol. Lett. 2016, 253, 4654. 